University of Michigan Law School

University of Michigan Law School Scholarship Repository

Law \& Economics Working Papers

$11-20-2015$

The Three Causes of Inversions: Reflections on Pfizer/Allergan and Notice 2015-79

Reuven S. Avi-Yonah

University of Michigan Law School, aviyonah@umich.edu

Follow this and additional works at: https://repository.law.umich.edu/law_econ_current

Part of the Business Organizations Law Commons

Working Paper Citation

Avi-Yonah, Reuven S., "The Three Causes of Inversions: Reflections on Pfizer/Allergan and Notice 2015-79" (2015). Law \& Economics Working Papers. 120.

https://repository.law.umich.edu/law_econ_current/120

This Article is brought to you for free and open access by University of Michigan Law School Scholarship Repository. It has been accepted for inclusion in Law \& Economics Working Papers by an authorized administrator of University of Michigan Law School Scholarship Repository. For more information, please contact mlaw.repository@umich.edu. 
DRAFT $11 / 20 / 15$

\title{
THE THREE CAUSES OF INVERSIONS: REFLECTIONS ON PFIZER/ALLERGAN AND NOTICE 2015-79
}

\author{
Reuven S. Avi-Yonah \\ The University of Michigan
}

\begin{abstract}
On November 19, 2015, Treasury released Notice 2015-79 (the "Notice"). The Notice represents Treasury's most recent response to the second wave of inversions, i.e., transactions in which US corporations become subsidiaries of foreign corporations without a meaningful change in their underlying business or in the location of their corporate headquarters. It follows on the heels of the announcement that Pfizer Inc. is considering a merger with Allergan PLC, an inverted Irish company, and supplements Notice 2014-52 from September 2014. ${ }^{1}$ Unfortunately, just like Notice 2014-52, the Notice is unlikely to stem the tide, and is even unlikely to stop Pfizer/Allergan. For that, stronger executive and legislative action is needed. To understand the issues, it is important to know about the history of inversions and the three reasons that drive them.
\end{abstract}

The first wave of inversions lasted from 1994 (Helen of Troy) until 2001 (Stanley) and was characterized by "naked" inversions, i.e., transactions in which the new foreign parent was a shell entity, usually incorporated in Bermuda (but resident in Barbados for treaty purposes). Naked inversions were stopped by the adverse public reaction to the Stanley inversion following 9/11, and were made impossible by the enactment of IRC section 7874 in 2004, which redefines the new foreign parent in a naked inversion as a domestic corporation.

The second wave of inversions builds on a loophole in section 7874, which excludes from the definition of "surrogate foreign corporation" (i.e., the new foreign parent) cases in which -

(iii) after the acquisition the expanded affiliated group which includes the entity [has] substantial business activities in the foreign country in which, or under the law of which, the entity is created or organized, when compared to the total business activities of such expanded affiliated group. ${ }^{2}$

This exception was meant to exclude "true" mergers with a foreign corporation that had "substantial business activities" in the foreign country it is incorporated in. The

${ }^{1}$ 2014-42 IRB 712 (Sep. 22, 2014).

${ }^{2}$ IRC 7874(a)(2)(b)(iii)(emphasis added). 
IRS defines "substantial business activities" as $25 \%$ of the "expanded affiliated group's" employees, assets, and gross income. ${ }^{3}$ Because of this rule, second wave inversions involve mergers with foreign targets that satisfy the $25 \%$ test. However, $75 \%$ of the combined entity can be the old US multinational, and the headquarters invariably remain in the US. In fact, both Pfizer/Allergan and the failed Mylan/Perrigo takeover (the two most recent high profile deals) involve mergers of two US companies that are only nominally foreign (Allergan and Perrigo are "Irish" and Mylan is "Dutch" but substantively they are all American).

The first wave of inversions was done for two reasons: First, since new foreign parent was not a CFC (as a publicly traded entity it did not have any $10 \%$ US shareholders, even if all the shareholders were US persons), it (and any of its foreign subsidiaries) could avoid Subpart F restrictions on the receipt of passive income and base company income. Second, New foreign parent could engage in earning stripping transactions with old US parent, in which up to $50 \%$ of old US parent's income could be "stripped" through interest deductions on loans from new foreign parent (in the case of royalties, $100 \%$ stripping is theoretically possible since the earnings stripping limits of IRC 163(j) only apply to interest).

In the second wave, a third reason was added: Since most US multinationals now have large amounts of income that is "trapped" in their CFCs and cannot be brought back because of the $35 \%$ tax on dividends (including deemed dividends under IRC 956), post-inversion structures were devised in which the CFCs lent or distributed their earnings to new foreign parent, which could then use it to buy back its shares or distribute dividends. Such "hopscotch" transactions (bypassing old US parent) were targeted by the Treasury in Notice 2014-52, which recharacterizes them as deemed dividends to old US parent under IRC 956.

The policy response to inversions depends to a significant extent on which of these three reasons drives the inversion.

If the main driver for inversions is Subpart $F$, the solution could be to relax the Subpart F rules (e.g., by abolishing the base company rule). But there is no evidence that recent inversions are driven by this reason. When the first wave of inversions began Subpart F still had real teeth, as indicated by the NFTC's 1999 plea to relax its limitations. Check the box (and its currently defunct but soon to be extended legislative companion IRC 954(c)(6)) did away with this problem, and other than 956, US multinationals no longer have a problem with Subpart F (as indicated by their ability to accumulate $\$ 2$ trillion in low tax jurisdictions offshore in a way that Stanley Surrey, the architect of Subpart F, would have found abhorrent).

If the main driver for inversions is accessing trapped earnings, the solution is (arguably) territoriality. But it is unlikely that this is the main problem, because (a) hopscotch transactions were targeted by Notice 2014-52, but inversions continue

${ }^{3}$ Treas Reg 1.7874-3 (finalized June 3, 2015). 
unabated; (b) not every inverting company has significant trapped earnings- for example, most of Perrigo's income is in the US; (c) other corporations with huge trapped earnings such as Apple, Google or Amazon are not inverting.

In my opinion, the main driver for most inversions both in the first and in the second wave is earnings stripping. The ability to reduce the 35\% US tax on US source earnings by half (via interest deductions) or more (via royalties) is the main reason that inversions result in a steep decline in the overall effective tax rate of the inverted company, and therefore in an increase in the value of its shares when the inversion is announced (although the latter may be short lived once the shareholders realize what the corporate governance implications are, as shown by the cases of Tyco (management fraud) and Mylan (management entrenchment)).

If that is the case, should the answer not be to reduce the corporate tax rate? I am in favor of doing so, but not because of inversions. We should reduce the rate because the burden on domestic US businesses is too high, and because it disincentivizes genuine FDI into the United States. The high rate (highest in OECD) also puts a lot of pressure on transfer pricing. Most of the $\$ 2$ trillion in trapped income probably belongs in the US from an economic perspective, but given the IRS' record in transfer pricing and cost sharing cases, proving so will be very hard.

But reducing the rate will not cure inversions for the simple reason that it is always possible to find a country with a lower rate to invert to. As long as there are Ireland, Luxembourg, Netherlands, Singapore and other jurisdictions with very low (single digits) effective corporate rates and local corporations that are large enough to meet the $25 \%$ threshold, inversions will continue. Saving half (or more) of $25 \%$ (a plausible new corporate tax rate) is a powerful incentive if the rate in the recipient country is $5 \%$ or less.

Thus, there is no solution to inversions except to prevent them by adopting the antiinversion rule proposed by the Obama Administration and introduced in Congress by Sen. Durbin and Rep. Doggett:

1. Redefine the 7874 threshold as $50 \%$ (to exclude only genuine mergers with larger foreign partners); and

2. Require moving the corporate headquarters.

In addition, I would suggest the following steps:

3. Abolishing the "substantial business activities" loophole;

4. Adding a corporate level exit tax (deemed sale of all assets) upon moving the headquarters; and 
5. Reducing the IRC $163(\mathrm{j})$ limit to $25 \%$ and applying it to both interest and royalties.

These actions should permanently solve the inversions problem. Inversions are simply a sub-type of corporate tax shelter: Transactions with no economic substance that are designed purely for tax avoidance. In an ideal world they would be struck down by 7701(o) (the economic substance rule), but since that is hard to enforce, we need more bright line rules to prevent further erosion of the US corporate tax base and further unfairness to ordinary domestic corporate and individual taxpayers who are left to pick up the tax tab.

But what can be done about inversions in the absence of legislative action? The basic problem is that most inversions are driven by earnings stripping, and it is hard to stop earnings stripping by executive action because the $50 \%$ limit and the limitation to interest and not royalties are in the Code. When it issued Notice 201452, Treasury suggested it would look at earnings stripping, but the Notice does not touch it. One promising avenue may be to redefine "interest" and "royalties" as not including payments to "surrogate foreign corporations" under the relevant tax treaties (with Ireland, the Netherlands etc.). That would subject payments to $30 \%$ withholding and eliminate the benefit of earnings stripping. It would be hard for the Irish and Dutch to object since the surrogate foreign parents are not really residents of Ireland or the Netherlands and should not be entitled to treaty benefits to begin with.

Instead, the Notice takes another tack: It excludes from the "substantial business activities" exception surrogate foreign corporations that are not treated as tax resident in the country they have the substantial business activities in. That is, if the foreign partner in an inversion has $25 \%$ of the combined group business activities in Ireland but is treated by the Irish as tax resident in a third country (or the US) because it is managed and controlled from there, the exception would not apply and the penalties imposed by section 7874 would (i.e., taxation of the inversion gain or treatment as a domestic corporation, depending on the level of US shareholders after the inversion). ${ }^{4}$

There are two problems with the approach of the Notice. First, it depends entirely on the view the Irish, Dutch etc. take of corporate residency. Managed and controlled is a flexible standard that can mean anything from the actual location of corporate headquarters in the UK to where the board meets once a year in Barbados. The Irish and Dutch like inversions and are therefore likely to define residency so as to escape the Notice.

4 The Notice also addresses various techniques to adjust the relative sizes of old US parent and new foreign parent to fit within the parameters of section 7874. These are unlikely to affect most inversion transactions. 
Second, like Notice 2014-52, the Notice depends on meeting the ownership thresholds of section 7874. This leaves out a transaction like Pfizer/Allergan, because Allergan is over $40 \%$ as large as Pfizer and therefore will never be a surrogate foreign corporation under 7874, regardless of its tax residency.

But could something be done about Pfizer/Allergan without legislative action? In my opinion the answer is yes. Unlike most inversions, Pfizer/Allergan is in fact driven by the wish to access trapped cash in Pfizer's CFCs, because (as Americans for Tax Fairness pointed out in an excellent report) Pfizer has already taken a reserve for the potential dividend tax on most of these earnings so that a successful inversion would dramatically increase its earnings per share by enabling it to reverse the reserve. $^{5}$

Pfizer/Allergan is not affected by Notice 2014-52 or by the Notice because both of them depend on meeting the $60 \%$ threshold of Code 7874. But the anti-hopscotch rule of Notice 2014-52 is a recharacterization of loans or distributions from CFCs of old US parent to new foreign parent (bypassing the US) as if they flowed through old US parent. That is, the approach of the 2014 Notice is tantamount to saying that the CFCs really lent or distributed the funds to their US parent, which in turn lent or distributed them to its foreign parent, triggering the deemed dividend tax of section 956 or the real dividend tax of section 301 .

However, this recharacterization does not depend on new foreign parent being a surrogate foreign corporation under section 7874. If Treasury can recharacterize hoptscotch transactions as flowing through the US under substance over form or step transaction principles, it can do so regardless of whether the ultimate ownership is $60 \%$ US, $50 \%$ US, or even $0 \%$ US- the recharacterization depends on the CFCs still being under old US parent and new foreign parent being above it, which is true in all cases, regardless of the identity of the ultimate shareholders.

Thus, in my opinion the Notice is weak. It is unlikely to affect many inversions, including Pfizer/Allergan. But Treasury could stop Pfizer/Allergan if it chose to do so by expanding the scope of Notice 2014-52 to include all hopscotch transactions, not just transactions with surrogate foreign corporations.

${ }^{5}$ See http://www.americansfortaxfairness.org/files/Pfizers-Tax-Dodging-Rx-StashProfits-Offshore-Final1.pdf. The report shows that Pfizer is losing money in the US so earnings stripping is unlikely to be the reason to invert in this case. 